\title{
Healthcare waste management as a tool for human health protection: a mini review
}

\author{
Gestão de resíduos de serviços de saúde como ferramenta para a proteção da saúde humana: uma \\ mini revisão
}

\section{La gestión de residuos sanitarios como herramienta para la protección de la salud humana: una mini revisión}

\author{
Ana Clara Muniz Pimenta \\ ORCID: https://orcid.org/0000-0002-6363-0566 \\ Ezequiel Dias Foundation, Brazil \\ E-mail: anaclaramuniz15@gmail.com \\ Susana Paixão \\ ORCID: https://orcid.org/0000-0002-4548-1894 \\ Polytechnic Institute of Coimbra., Portugal \\ E-mail: supaixao@hotmail.com \\ Arthur Couto Neves \\ ORCID: https://orcid.org/0000-0003-2829-0663 \\ Federal Center of Technological Education of Minas Gerais, Brazil \\ E-mail: coutoarthur@gmail.com \\ Marcos Paulo Gomes Mol \\ ORCID: https://orcid.org/0000-0002-2568-3579 \\ Ezequiel Dias Foundation, Brazil \\ E-mail:marcos_mol@yahoo.com.br
}

\begin{abstract}
Healthcare wastes are generated by human or animal healthcare facilities. A small portion of these wastes are considered dangerous. However, accidents generated by incorrect waste management is a reality around the world. Accidents happen in different management stages, from the waste generation to its final destination, if waste is not properly managed. Therefore, this work aimed to discuss the possible problems related to the incorrect healthcare waste management, focusing on public health. This mini-review discussed some of the ways in which waste management can favor the preservation of public health and the environment, through steps such as minimization, segregation and recycling.
\end{abstract}

Keywords: Medical waste; Public health; Waste generation; Work accident.

\section{Resumo}

Resíduos de serviços de saúde são gerados por estabelecimentos de atendimento à saúde humana ou animal. Uma pequena parte desses resíduos é considerada perigosa. No entanto, acidentes decorrentes do gerenciamento incorreto destes resíduos são uma realidade em todo o mundo. Os acidentes acontecem em diferentes etapas do gerenciamento, desde a geração dos resíduos até sua destinação final, caso não sejam gerenciados adequadamente. Portanto, o presente trabalho discutiu os problemas relacionados com a gestão incorreta dos resíduos de serviços de saúde, focando nas implicações à saúde pública. Essa mini revisão discutiu algumas das formas pelas quais o gerenciamento de resíduos pode favorecer a preservação da saúde pública e do meio ambiente, por meio de etapas como minimização, segregação e reciclagem.

Palavras-chave: Resíduos de serviços de saúde; Saúde pública; Geração de resíduos; Acidente do trabalho.

\section{Resumen}

Los desechos sanitarios son generados por instalaciones sanitarias para humanos o animales. Una pequeña parte de estos desechos se considera peligrosa. Sin embargo, los accidentes generados por una incorrecta gestión de residuos es una realidad en todo el mundo. Los accidentes ocurren en diferentes etapas de gestión, desde la generación de residuos hasta su destino final, si los residuos no se gestionan adecuadamente. Por lo tanto, este trabajo tuvo como objetivo discutir los posibles problemas relacionados con la incorrecta gestión de los residuos sanitarios, centrándose en la salud pública. Esta mini revisión discutió algunas de las formas en que la gestión de residuos puede favorecer la preservación de la salud pública y el medio ambiente, a través de pasos como la minimización, la segregación y el reciclaje.

Palabras clave: Residuos sanitários; Salud pública; Generación de residuos; Accidente de trabajo. 


\section{Introduction}

The proper healthcare waste (HCW) management is important for public health and environment protection. This waste is potentially dangerous due to the presence of infectious, chemical, radioactive or sharp materials (Tesfahun et al, 2014; WHO, 2018). HCW is usually generated in institutions that provide human or animal healthcare services, such as hospitals, veterinary clinics, and laboratories (Ribeiro et al, 2020).

Good waste management practices are easily achieved through the elaboration and implementation of a Healthcare Waste Management Plan (HCWMP), describing the strategies of segregation, packaging, collection, storage, transport, destination and final disposal of wastes, according to characteristics of each waste being generated. In addition, the HCWMP must contain actions to prevent possible impacts to public health the environment (Ribeiro et al, 2020; Costa et al, 2019).

Hazardous waste represents $15 \%$ of total $\mathrm{HCW}$ generated by healthcare facilities (WHO, 2018). Incorrect management of HCW may be associated with: injuries caused by sharp materials, which may contain the presence of infectious agents such as hepatitis B or C viruses (Arafa and Eshak, 2019; Mol et al, 2015); infection caused by high transmission agents present in inpatients wastes (Tesfahun et al, 2014; WHO, 2018; Idowu et al, 2013); dangers associated with toxic products in the environment such as chemicals, antibiotics, and cytotoxic drugs (WHO, 2018). Due to the coronavirus pandemic scenario, this topic gets even greater importance when considering risks of infected material being discharged (Mol and Caldas, 2020; Urban and Nakada, 2020).

Recently, it can be said that the HCW generation has been rising due to the complexity of healthcare services provided by establishments as hospitals, clinics, and the incised accessibility for a broader population to a heath care (Khan et al, 2019). As shown by Ansari et al. (2019), HCW generation variates according to the generators location. There is a wide range variation in hospitals, the range goes from India 0,24; Turkey 0,63; Egypt 0,87; Iran 3,94; Brazil 4,37 and India 6,03, values in $\mathrm{kg} / \mathrm{bed}$.day.

While WHO guidelines are followed in countries such as Canada, United Kingdom and United States, the scenario is different in Asian countries, mainly those considered still in development, that suffer a lack of resources for HCW management regulatory organizations (Khan et al, 2019).

Population growth leads to necessary expansion of establishments that offer health services. Consequently, the waste generation rates also tend to increase according to the establishment's location, usually related to the characteristics such GDP, and the availability of human, financial and structure resources. In some metropolitan cities, it was found that around 30 tons of biomedical waste are produced per day in hospitals (Manzoor and Sharma, 2019). Incorrect management of these wastes can lead to contamination of soil, water, air and bring health problems to the general population (Tesfahun et al, 2014; WHO, 2018; Costa et al, 2019; Manzoor and Sharma, 2019).

Therefore, this work aimed to discuss the possible problems related to the incorrect healthcare waste management, focusing on public health.

\section{Methodology}

A mini-review was carried out discussing the relationship between poor healthcare waste management and public health negative impacts. The focus was to identify research discussing the risks to public health in the face of incorrect management of this waste, in order to identify each impact associated with management stages.

\section{Results and Discussion}

In view of the risks associated with poor waste management, the correct $\mathrm{HCW}$ management presents waste minimization strategies, usually through segregation at the moment of waste generation, permitting the correct disposal. Figure 
1 shows HCW management stages and the main health risks associated.

Figure 1: Association between HCW management stages and the main health risks.

\section{MANAGEMENT STEPS}

Waste Generation

Classification

\section{Segregation}
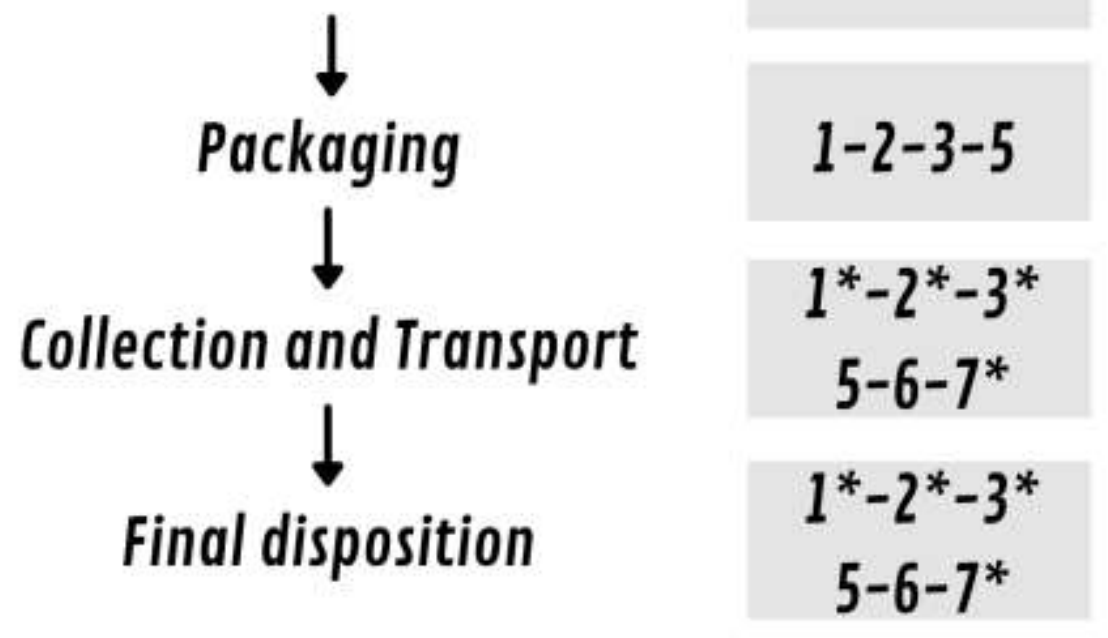

\section{RISK CONSIDERING INCORRECT PROCEDURES}

\section{CAPTION}

1. Sharp Injury

2.Infection by pathogenic agent

3. Chermical or radioctive contamination

4. Contamination of common waste

\section{Employee exposure}

6. Soil, air and water contamination

7. Disease transmission to the population

*risk considering fail in packaging procedures or incorrect magament

Source: Authors.

Some factors that make infections possible, as pointed out in Figure 1, may be associated with insufficient occupational training, incorrect or incomplete use of personal protective equipment, and insufficient knowledge about the pathogen' transmission way. A study carried out by Zajac et al. (2016), in a public hospital, showed that accidents with sharps were mostly caused during healthcare services, that is, during the generation of waste, and not in the following stages of management. After identifying the problem and applying proposals to solve it, the number of accidents dropped. This shows us that the identification of flaws in the waste management process is essential for the correct disposal of these wastes. 
It is possible to notice that some of the risks are associated with previous stages of management, principally the segregation stage. It consists of the waste separation into a determinate classification, usually presented by a healthcare regulatory organization, ideally performed at the time and place of waste generation (Costa et al, 2019; Nazari et al, 2000). The incorrect segregation of $\mathrm{HCW}$ is directly linked to the lack of training and awareness on the part of the staff of the establishments, in addition to a low investment in this stage of management, making common waste potentially hazardous when mixed with healthcare wastes (Khan et al, 2019; Akkajit et al, 2020; Domingo et al, 2020). The prior training of employees is essential for the proper functioning of this stage and the non-commitment of the others.

Collection and transport stages represent another particular health risks, when poor managed. The optimization of the collection and disposal model network aiming to minimize transportation is proposed by Homayouni and Pishvaee (2020) as essential for controlling health risks and waste management costs. Yao et al. (2020) and Gao et al. (2021) also pointed out the establishment of proper $\mathrm{HCW}$ center to minimize pollution, negative environment problems and also health risks.

Currently, with the new coronavirus (covid-19) pandemic scenario, another concern arises regarding the waste generated by patients undergoing home treatment, which generate waste potentially contaminated (Mol and Caldas, 2020). When these wastes are mixed with the other residues waste in that household, there is a risk in the stage of collection and transport of these materials, since in the literature it has been shown that the virus can resist on some surfaces for up to several hours. To minimize these risks, it is important to correctly store and identify these wastes.

In addition, increased production and incorrect disposal of waste such as face masks can be seen throughout the pandemic. An estimate made by Urban and Nakada (2020) showed that, potentially, more than 85 million masks are being used daily in Brazil. Therefore, the generation of this new type of waste becomes a new demand for analysis by the managers of urban cleaning services in the municipalities.

The minimization and segregation of waste, when implemented correctly, provides a reduction in the risks associated with waste from healthcare services. Minimizing waste consists in reducing generation even before the conditioning and storage phases and includes any reduction of waste from the generating source, reduction of the total volume and reduction of its toxicity. It is one of the first and most important aspects to be considered in preventing environmental impacts. It is possible to minimize the generation of waste and bring economic and environmental benefits by reducing the use of the material in its generating source, or even by sending it for recycling.

\section{Conclusion}

Aware of the potential environmental and health impacts associated with HCW when managed inappropriately, the measures proposed for the management of this waste through the HCWMP, such as minimization, segregation, and recycling and the correct training of all staff responsible for handling the HCW, are essential to ensure the protection of both the population and the environment, preventing possible accidents and disasters caused by inappropriate practices.

Thus, minimization is the most important step in waste management and must be prioritized in all facilities where $\mathrm{HCW}$ are generated. Minimizing waste action represent preserving sources, reducing total volume and toxicity of the HCW generated. It is one of the first and most important aspects to be considered in preventing health risks and environmental impacts. Through this extra attention given to $\mathrm{HCW}$ it is possible to avoid the destination of a significant volume of waste to unnecessary treatment and disposal in landfills, thus, mitigating and reducing environmental negatives impacts.

Considering all known risks involved in HCW management, and the difficult of mitigate or avoid them, turns the process from waste generation until its final destination a challenge for those responsible for the HCW control. This is particularly highlighted in locations where human and financial resources are sparse, and therefore, due to the lack of knowledge and invests the waste is managed incorrectly. Future works should discuss in more details the HCW management 
practices, aiming to show the risk management and different diseases associated with biological wastes.

\section{Acknowledgments}

The authors disclosed receipt of the following financial support for the research, authorship and/or publication of this article: Financial support provided by Fundação de Amparo à Pesquisa do Estado de Minas Gerais (FAPEMIG) and Conselho Nacional de Desenvolvimento Científico e Tecnológico (CNPq). Technical support was provided by Ezequiel Dias Foundation (FUNED). Also, we are grateful to Luiz Gustavo de Oliveira Schenk, for the translation and English grammar review

\section{References}

Akkajit P., Romin, H., Assawadithalerd, M., Al-Khatib, I.A. (2020) Assessment of knowledge, attitude, and practice in respect of medical waste management among healthcare workers in clinics. Journal of Environmental and Public Health, 2020:1-12, doi 10.1155/2020/8745472

Ansari, M., Ehrampoush, M.H., Farzadkia, M., Ahmadi, E. (2019) Dynamic assessment of economic and environmental performance index and generation, composition, environmental and human health risks of hospital solid waste in developing countries; A state of the art of review. Environment International. 132(105073). Doi https://doi.org/10.1016/j.envint.2019.105073

Arafa, A; Eshak, E.S. (2019) Medical waste handling and hepatitis B virus infection: A meta-analysis. American Journal of Infection Control. 48(3):316-319. doi: 10.1016/j.ajic.2019.08.011.

Costa, C.A.; Maia, C.C.; Neves, AC., Barros, R.T.V., Mol, M.P.G. (2019) Profile of highly infected wastes generated by hospitals: A case in Belo Horizonte, Brazil. Waste Management and Research. 37(6):643-650. doi:10.1177/0734242X19846296

Domingo, J.L., Marquès, M., Mari, M., Schuhmacher, M. (2020) Adverse health effects for populations living near waste incinerators with special attention to hazardous waste incinerators. A review of the scientific literature. Environmental Research., 187(109631). doi 10.1016/j.envres.2020.109631

Gao, J., Li, H., Wu, J., Lyu, J., Tan, Z., Jin, Z. (2021) Routing optimisation of urban medical waste recycling network considering differentiated collection strategy and time windows. Sci. Program., 2021 (2021), pp. 1-11, 10.1155/2021/5523910

Homayouni, Z., Pishvaee, M.S. (2020) A bi-objective robust optimization model for hazardous hospital waste collection and disposal network design problem. Journal of Material Cycles and Waste Management volume. 22(2020):1965-1984, doi 10.1007/s10163-020-01081-8

Idowu I, Alo B, Atherton W, et al. (2013). Profile of medical waste management in two healthcare facilities in Lagos, Nigeria: a case study. Waste Management \& Research 31:494-501.

Khan BA, Cheng L, Khan AA, Ahmed H. (2019) Healthcare waste management in Asian developing countries: A mini review. Waste Management \& Research. 37(9):863-875. doi:10.1177/0734242X19857470

Manzoor, J., \& Sharma, M. (2019). Impact of Biomedical Waste on Environment and Human Health. Environmental Claims Journal, 1-24. doi:10.1080/10406026.2019.1619265

Mol MPG, Caldas S. (2020) Can the human coronavirus epidemic also spread through solid waste? Waste Management \& Research. 38(5):485-486. doi:10.1177/0734242X20918312.

Mol MPG, Greco DB, Cairncross S, Heller L. (2015) Hepatitis B and C in household and health services solid waste workers. Cadernos de Saúde Pública, 31:Sup, 295-300. Doi: http://dx.doi.org/10.1590/0102-311X00083814

Nazari, Mateus Torres et al. (2020) Incidência de resíduos de serviços de saúde em cooperativas de triagem de materiais recicláveis. Eng. Sanit. Ambient., Rio de Janeiro, v. 25, n. 2, p. 271-279.

Ribeiro PAM; Neves, AC; Mol MPG. (2020) Quantitative estimation of healthcare wastes generated by brazilian hospitals: a literature review. Environmental Engineering and Management Journal 19:7, 1143-1156.

Tesfahun E, Kumie A, Legesse W et al. (2014). Assessment of composition and generation rate of healthcare wastes in selected public and private hospitals of Ethiopia. Waste Management \& Research 32(3):215-220.

Urban, RC; Nakada, LYK. (2020) COVID-19 pandemic: Solid waste and environmental impacts in Brazil. Science of The Total Environment. 755:Part 1. doi: https://doi.org/10.1016/j.scitotenv.2020.142471

WHO, World Health Organization (2018). Available at <https://www.who.int/news-room/fact-sheets/detail/health-care-waste> acessed 25 Feb. 2021

Yao, L., Xu, Z., Zeng, Z.(2020) A soft-path solution to risk reduction by modeling medical waste disposal center location-allocation optimization. Risk Anal., 40 (2020), pp. 1863-1886, 10.1111/risa.13509

Zajac, M.A.L., Fernandes, C.J.D., Aquino, S. (2016) Reverse logistics of class-d waste in a hospital environment: monitoring and evaluation of recycling in the Candido Fontoura Children's Hospital. Revista de Gestão Ambiental e Sustentabilidade. 5(1):78-92. 